\title{
Genetic diversity of pacu and piapara broodstocks in restocking programs in the rivers Paraná and Paranapanema (Brazil)
}

\section{Diversidade genética de estoques de Pacu e Piapara em programas de repovoamento nos rios Paraná e Paranapanema (Brasil)}

\author{
Nelson Mauricio Lopera-Barrero ${ }^{1 *}$; Jayme Aparecido Povh ${ }^{2}$; \\ Rodolfo Nardez Sirol'; Maria del Pilar Rodriguez-Rodriguez; \\ Ed Christian Suzuki de Lima ${ }^{5}$; Angela Rocio Poveda-Parra ${ }^{6}$; \\ Felipe Pinheiro de Souza ${ }^{7}$; Pâmela Juliana Furlan Murari ${ }^{8}$; \\ Rodrigo Alejandro Arellano Otone ${ }^{9}$; Ricardo Pereira Ribeiro ${ }^{10}$
}

\begin{abstract}
The genetic diversity of Piaractus mesopotamicus (pacu) and Leporinus elongatus (piapara) broodstocks used in restocking programs in the rivers Paraná and Paranapanema is analyzed. One hundred and twenty specimens (two broodstocks of each species) from fish ponds in Palotina PR Brazil and in Salto Grande SP Brazil were assessed. Ten primers produced 96 fragments, comprising 68 (70.83\%) and 94 (97.92\%) polymorphic fragments for P. mesopotamicus and L. elongatus broodstocks, respectively. Differences $(\mathrm{p}<0.05)$ in the frequency of 15 and 27 fragments were detected for each species, without exclusive fragments. Shannon Index $(0.347-0.572)$ and the percentage of polymorphic fragments $(57.3 \%-94.8 \%)$ revealed high intra-population genetic variability for all broodstocks. Results of molecular variance analyses (AMOVA) showed that most variations do not lie between the broodstocks but within each broodstock (89\%). Genetic $(0.088$ and 0.142$)$ and identity $(0.916$ and 0.868$)$ distance rates demonstrated similarity between the broodstocks of each species, corroborated by Fst $(0.1023$ and 010.27) and $\mathrm{Nm}$ (4.18 and 4.33) rates, with a slight genetic difference due to genic flux. High intrapopulation genetic variability and similarity between the broodstocks of each species was also detected, proving a common ancestry.
\end{abstract}

Key words: Broodstocks. Genetic conservation. Genetic variability. Leporinus elongatus. Piaractus mesopotamicus.

${ }^{1}$ Prof. Dr., Departamento de Zootecnia, Programa de Pós-Graduação em Ciência Animal, Universidade Estadual de Londrina, UEL, Londrina, PR, Brasil. E-mail: nmlopera@uel.br

2 Prof. Dr., Universidade Federal de Mato Grosso do Sul, UFMS, Campo Grande, MS, Brasil. E-mail: jayme.peixegen@gmail.com

3 Pesquisador, Dr. em Zootecnia, Companhia Paulista de Força e Luz, CPFL, Campinas, SP. E-mail: rnsirol@cpfl.com.br

${ }^{4}$ Dr $^{\text {a }}$ Pesquisadora, Universidade Federal dos Vales de Jequitinhonha e Mucuri, UFVJM, Campus JK, Diamantina, MG, Brasil. E-mail: rodrigpilar@gmail.com

5 Mestre, Pesquisador, UEL, Londrina, PR, Brasil. E-mail: edchris7@hotmail.com

${ }^{6}$ Pós-Doutoranda, Departamento de Zootecnia, UEL, Londrina, PR, Brasil. E-mail: angelapovedaparra@hotmail.com

7 Discente do Curso de Mestrado do Programa de Pós-Graduação em Ciência Animal, UEL, Londrina, PR, Brasil. E-mail: felipeps1991@gmail.com

${ }^{8}$ Discente do Curso de Doutorado do Programa de Pós-Graduação em Ciência Animal, UEL, Londrina, PR, Brasil. E-mail: pamela. furlan@outlook.com

9 Prof. Dr., Centro Universitário Filadélfia, UNIFIL, Londrina, PR, Brasil. E-mail: otonel.rodrigo@gmail.com

${ }^{10}$ Prof. Dr, Departamento de Zootecnia, Programa de Pós-Graduação em Zootecnia, Universidade Estadual de Maringá, UEM, Maringá, PR, Brasil. E-mail: rpribeiro@uem.br

* Author for correspondence 


\section{Resumo}

O objetivo da pesquisa foi analisar a diversidade genética de estoques de Pacu (Piaractus mesopotamicus) e Piapara (Leporinus elongatus) utilizados em programas de repovoamento dos rios Paraná e Paranapanema. Foram analisados 120 exemplares (dois estoques de cada espécie) de pisciculturas das cidades de Palotina (Paraná) e da cidade de Salto Grande (São Paulo). Os 10 iniciadores produziram 96 fragmentos, dos quais $68(70,83 \%)$ e $94(97,92 \%)$ foram polimórficos para os estoques de $P$. mesopotamicus e L. elongatus, respectivamente. Foram observadas diferenças $(\mathrm{P}<0,05)$ na frequência de 15 e 27 fragmentos para cada espécie, sem a presença de fragmentos exclusivos. Os valores do índice de Shannon $(0,347$ a 0,572$)$ e da porcentagem de fragmentos polimórficos $(57,3 \%$ a $94,8 \%)$ mostraram uma alta variabilidade genética intra-populacional para todos os estoques. Os resultados das análises de variância molecular (AMOVA) mostraram que a maior parte da variação está dentro de cada estoque (89\%) e não entre os estoques. Os valores da distância $(0,088$ e 0,142$)$ e identidade $(0,916$ e 0,868$)$ genética demonstraram que existe similaridade entre os estoques de cada espécie, sendo corroborado pelos valores de Fst $(0,1023$ e 010,27) e Nm $(4,18$ e 4,33) que mostraram uma moderada diferenciação genética com presença de fluxo gênico. Foi observada alta variabilidade genética intra-populacional e similaridade entre os estoques de cada espécie demonstrando uma origem em comum.

Palavras-chave: Conservação genética. Leporinus elongatus. Estoques de reprodutores. Piaractus mesopotamicus. Variabilidade genética.

\section{Introduction}

Brazil has a great diversity of native fish with relevant characteristics for breeding and with great commercial capacity (MARENGONI et al., 2006; BOSCOLO et al., 2011). Due to their excellent zootechnical traits for fish cultivation and to their high commercial and cultural value for riverine populations of the populations living near the rivers Paraná and Paranapanema, the Piaractus mesopotamicus (pacu) and the Leporinus elongatus (piapara) may be highlighted among migratory native fish species in Brazil. However, deforestation, deterioration of river waters, climatic changes and hydroelectric plants reduced natural broodstocks in Brazilian rivers (HATANAKA et al., 2006; LOPERA-BARRERO, 2009).

Although restocking programs are increasingly employed in Brazilian rivers as conservation strategies (SIROL; BRITTO, 2006), they must be foregrounded on a scientific base that would determine reproduction, genetic and biological methodologies without a decrease in genetic variability of broodstocks and consequently of natural populations in the rivers. Genetic monitoring of the populations in restocking programs are highly relevant (LOPERA-BARRERO, 2009; POVH et al., 2008a), with special reference to dominant molecular markers (POVH et al., 2008b; GANAIE; ALI, 2016).

Due to dominant molecular markers, RAPD techniques are efficient to calculate precisely and inexpensively the genetic variability in simple population studies, including restocking programs of native populations. Reviews published during the last five years (ABD EL NABY et al., 2015; ALMEIDA et al., 2013; BEHRMANN et al., 2015; GANAIE; ALI, 2016; GOMES et al., 2013; HASAN; GOSWAMI, 2015; LOPERA-BARRERO et al., 2015; RAMOS et al., 2012; RIBEIRO et al., 2016) have shown that, in spite of the influence of several factors in technique, optimization protocols produced reliable results which have been accepted by the scientific community worldwide.

Current assay investigates the genetic diversity of $P$. mesopotamicus and L. elongatus broodstocks employed in restocking programs in the rivers Paraná and Paranapanema, Brazil. 


\section{Materials and Methods}

One hundred and twenty samples of caudal fins $\left(0.5 \mathrm{~cm}^{2}\right)$ from four broodstocks $(30$ samples per broodstock) were collected. Two broodstocks of P. mesopotamicus (PacPAL) and L. elongatus (PiaPAL) were retrieved from a fish pond in Palotina PR Brazil (24 $\left.12^{\prime} \mathrm{S} ; 3^{\circ} 50^{\prime} \mathrm{W}\right)$ and used for restocking programs in the river Paraná. The other two broodstocks P. mesopotamicus (PacSG) and L. elongatus (PiaSG) were retrieved from the Aquaculture and Hydrology Station of Duke Energy International in Salto Grande SP Brazil (22 54' S; $50^{\circ} 00^{\prime} \mathrm{W}$ ) used for restocking programs in the river Paranapanema.

$\mathrm{NaCl}$ methodology, described by Lopera-Barrero et al. (2008), was employed for DNA extraction, quantified by spectrophotometer Shimadzu UV 1601, with wave length $260 \mathrm{~nm}$ and samples diluted for a concentration of $10 \mathrm{ng} \mu \mathrm{L}^{-1}$. DNA integrity was verified by horizontal electrophoresis in agar gel $1 \%$ by buffer TBE $1 \mathrm{X}$ (500 mM Tris-HC1, 60
$\mathrm{mM}$ boric acid and $83 \mathrm{mM}$ EDTA). Gel was stained with ethidium bromide $\left(0.5 \mathrm{mg} \mathrm{mL}^{-1}\right)$ for 30 minutes and image obtained by EDAS (Kodak 1D Image Analysis 3.5).

Amplification followed procedures by Williams et al. (1990), modified. DNA was amplified in a $15 \mathrm{~mL}$ reaction volume using buffer $1 \mathrm{X}$ Tris$\mathrm{KCl}, 2.5 \mathrm{mM} \mathrm{MgCl}{ }^{2}, 0.46 \mu \mathrm{M}$ primer, $0.2 \mathrm{mM}$ of each dNTP, a Platinun Taq DNA Polimerase unit (Invitrogen $\AA$, USA) and 10 ng target DNA. DNA was denatured at $94^{\circ} \mathrm{C}$ for four minutes, followed by 40 cycles, every one consisting of one minute denaturation at $94^{\circ} \mathrm{C} ; 90$ seconds of primer annealing at $40^{\circ} \mathrm{C}$ and two minutes extension at $72^{\circ} \mathrm{C}$. A final extension at $72^{\circ} \mathrm{C}$ was performed for seven minutes. RAPD reactions were amplified in a thermocycler Eppendorf Mastercycler Gradient and 30 different primers were tested with 10 bases for kits OPA, OPW and OPX (Operon Technologies Ltd. Valencia, USA), from which the most reproducible and best defined were selected (Table 1).

Table 1. Sequence of primers and nucleotides, percentage of puric bases $(\mathrm{G}+\mathrm{C})$, number of fragments $(\mathrm{n})$ and base pairs of fragmente in P. mesopotamicus (A) and L. elongatus (B) broodstocks.

\begin{tabular}{ccccccc}
\hline Primers & Sequence & G+C & $\mathrm{n}(\mathrm{A})$ & Size (A) & $\mathrm{n}(\mathrm{B})$ & Size (B) \\
\hline OPA02 & TGC CGA GCT G & 70 & 7 & $200-1100$ & 7 & $350-1200$ \\
OPA04 & AAT CGG GCT G & 60 & 6 & $500-1200$ & 6 & $400-1300$ \\
OPA16 & AGC CAG CGA A & 60 & 12 & $300-1700$ & 14 & $200-1700$ \\
OPW01 & CTC AGT GTC C & 60 & 10 & $300-1700$ & 7 & $300-1500$ \\
OPW02 & ACC CCG CCA A & 70 & 10 & $500-1800$ & 10 & $400-1500$ \\
OPW03 & GTC CGG AGT G & 70 & 11 & $300-1700$ & 10 & $400-1500$ \\
OPW04 & CAG AAG CGG A & 60 & 7 & $400-1500$ & 8 & $500-1400$ \\
OPW08 & GAC TGC CTC T & 60 & 9 & $300-1400$ & 9 & $400-1500$ \\
OPX01 & CTG GGC ACG A & 70 & 9 & $400-1500$ & 10 & $300-1800$ \\
OPX03 & TGG CGC AGT G & 70 & 8 & $400-1300$ & 9 & $400-1700$ \\
OPX04 & CCG CTA CCG A & 70 & 7 & $300-1300$ & 6 & $400-1300$ \\
Total & --- & --- & 96 & $200-1800$ & 96 & $200-1800$ \\
\hline
\end{tabular}

Amplification products were separated in agar gel $1.5 \%$ and $15 \mathrm{~mL}$ of the amplified product and $2 \mathrm{~mL}$ of sample buffer ( $40 \%$ sucrose and $0.25 \%$ bromophenol blue) in horizontal electrophorese were used. Electrophorese was conducted in a buffer TBE $0.5 \mathrm{X}$ (45 mM Tris-Borate and $1 \mathrm{mM}$ 
EDTA) for four hours at 70 volts. Quantification and amplification gels were visualized by UV radiation after exposure with ethidium bromide $(0.5$ $\mathrm{mg} / \mathrm{mL}^{-1}$ ) for one hour. Image was photographed with Kodak EDAS (Kodak 1D Image Analysis 3.5, USA). Blank samples in gels (without DNA), double amplifications and electrophoresis, coupled to a strict selection of fragments enhanced quality and reproducibility of the amplified products

Fragment size obtained by amplification was estimated by comparing with standard Ladder 100 bp (Invitrogen ${ }^{\circledR}$, USA). The presence or absence of fragments of identical molecular size constructed a similarity matrix based on Jaccard's similarity coefficient, with 1 as the presence of the fragment and 0 as its absence.

Genetic variability was determined by Shannon's genetic diversity index and by the percentage of polymorphic fragments calculated with PopGene 1.31 (YEH et al., 1999). TFPGA 1.3 (MILLER, 1997) calculated the distance and genetic identity (NEI, 1978) between broodstocks and the frequency of exact fragments (RAYMOND; ROUSSET, 1995). Arlequin 3.0 (EXCOFFIER et al., 2007) determined the genetic difference between broodstocks by Fst (WEIR; COCKERHAM, 1984) and for the analyses of molecular variance (AMOVA) (EXCOFFIER et al., 1992). Significance level of estimates was calculated by the randomized permutations method with 1000 and 10000 permutations. The same program was employed to determine the effective number of migrants (Nm). Wright (1978) proposal was employed for differentiation level by which rates between 0.00 and $0.05 ; 0.051$ and $0.15 ; 0.151$ and 0.25 and $>0.25$ respectively indicate small, medium, high and very high genetic differentiation. Statistical significance of Fst was calculated by test $\mathrm{X}^{2}\left[\mathrm{c}^{2}=2 \mathrm{n}\right.$ Fst $\left.(\mathrm{k}-1) ; \mathrm{GL}=(\mathrm{k}-1)(\mathrm{s}-1)\right]$, suggested by Workman and Niswander (1970), where $n$ is the number of specimens in each group; $\mathrm{k}$ is the number of alleles; $\mathrm{s}$ is the number of groups.

\section{Results and Discussion}

The 10 primers produced 96 fragments varying between six (OPA04) and twelve (OPA16) ( $P$. mesopotamicus broodstocks) and between six (OPA04 - OPX04) and 14 (OPA16) (L. elongatus broodstocks), featuring $68(70.83 \%)$ and 94 (97.92\%) polymorphic fragments for the two species respectively (Table 1). According to Telles et al. (2001), the number of fragments was sufficient to calculate reliable genetic variability.

There was a difference $(\mathrm{P}<0.05)$ in the frequency of fragments in P. mesopotamicus (15 fragments) and L. elongatus (27 fragments) broodstocks. Ten limiting fragments (fragments with frequency $1,000)$ were observed in the $P$. mesopotamicus broodstock in Palotina (PacPAL) but not reported in the broodstock in Salto Grande (PacSG). Low frequency fragments (less than 0.100) were not extant in the broodstocks (Table 2). On the other hand, L. elongatus broodstocks (Piapara Palotina: PiaPAL and Piapara Salto Grande: PiaSG) revealed limiting fragments in the two stocks (PiaPAL: 9; PiaSG: 3) and one low frequency fragment (primer OPA04 - 1300 bp) (Table 3). There were no exclusive fragments in the broodstocks, presupposing possible genetic similarity.

Shannon Index (SI) of genetic variability and percentage of polymorphic fragments (\%PF) revealed high rates of intra-population genetic variability for all broodstocks (Table 4) even with fixed alleles (limiting) in several broodstocks. In fact, genetic variability was preserved in the fish ponds. probably due to the fact that a sample with sufficient genetic pool was provided at its formation and which prevented the founding effect. According to Lopera-Barrero (2009), the first thing to undertake in the implantation of pisciculture or restocking programs is the verification of broodstocks' genetic variability. If low genetic variability occurs, low survival rates and adaptation to the environment of released offspring will result. 
Table 2. Primers (I), size (Tam) and frequency of fragments with significant rates by exact test ( $\mathrm{P}>0.05)$ for $P$. mesopotamicus broodstock.

\begin{tabular}{ccccc}
\hline \multirow{2}{*}{$\mathrm{I}$} & Tam(A) & \multicolumn{2}{c}{ Frequency } & \multirow{2}{*}{$\mathrm{P}^{3}$} \\
\cline { 3 - 4 } & & PacPAL $^{1}$ & PacSG $^{2}$ & 0.001 \\
$\mathrm{~A} 02$ & 300 & 0.742 & 0.423 & 0.000 \\
$\mathrm{~A} 04$ & 700 & 0.817 & 0.317 & 0.000 \\
$\mathrm{~A} 16$ & 1500 & 0.817 & 0.367 & 0.000 \\
& 1700 & 1.000 & 0.293 & 0.000 \\
$\mathrm{X} 01$ & 500 & 1.000 & 0.247 & 0.000 \\
& 600 & 1.000 & 0.422 & 0.001 \\
& 800 & 0.517 & 0.225 & 0.000 \\
$\mathrm{X}$ & 1200 & 1.000 & 0.293 & 0.000 \\
& 500 & 1.000 & 0.394 & 0.001 \\
& 800 & 1.000 & 0.484 & 0.000 \\
$\mathrm{X} 04$ & 1100 & 1.000 & 0.367 & 0.000 \\
& 300 & 1.000 & 0.342 & 0.000 \\
& 400 & 0.635 & 0.247 & 0.000 \\
W01 & 1200 & 1.000 & 0.293 & 0.000 \\
\hline
\end{tabular}

${ }^{1} \mathrm{PacPAL}=$ pacu Palotina; ${ }^{2} \mathrm{PacSG}=$ pacu Salto Grande; ${ }^{3} \mathrm{P}$ : probability.

Table 3. Primers (I), size (Tam) and frequency of fragments with significant rates by exact test $(\mathrm{P}>0.05)$ for $L$. elongatus broodstocks.

Continue ...

\begin{tabular}{ccccc}
\hline \multirow{2}{*}{$\mathrm{I}$} & Tam (B) & \multicolumn{2}{c}{ Frequency } & \multirow{2}{*}{$\mathrm{P}^{3}$} \\
\cline { 2 - 4 } $\mathrm{A} 02$ & 450 & PiaPAL $^{1}$ & PiaSG $^{2}$ & 0.000 \\
& 1200 & 1.000 & 0.342 & 0.004 \\
$\mathrm{~A} 04$ & 400 & 0.553 & 0.293 & 0.000 \\
& 600 & 1.000 & 0.204 & 0.000 \\
& 700 & 1.000 & 0.225 & 0.000 \\
& 1000 & 1.000 & 0.247 & 0.000 \\
& 1200 & 1.000 & 0.270 & 0.000 \\
$\mathrm{~A} 16$ & 1.000 & 0.247 & 0.000 \\
& 200 & 0.517 & 0.069 & 0.000 \\
& 600 & 1.000 & 0.394 & 0.001 \\
& 1100 & 0.553 & 0.270 & 0.000 \\
$\mathrm{X} 01$ & 1700 & 1.000 & 0.342 & 0.002 \\
& 300 & 0.553 & 0.247 & 0.001 \\
$\mathrm{X} 03$ & 500 & 0.553 & 0.247 & 0.000 \\
W01 & 500 & 1.000 & 0.270 & 0.001 \\
W01 & 600 & 0.144 & 0.394 & 0.004 \\
W03 & 950 & 0.184 & 0.484 & 0.001 \\
& 700 & 0.342 & 0.684 & 0,006 \\
& 1300 & 0.247 & 0.452 & 0.006
\end{tabular}




\begin{tabular}{ccccc} 
W04 & & & & ... Continuation \\
& 500 & 0.183 & 0.452 & 0.001 \\
& 600 & 0.204 & 0.423 & 0.003 \\
W08 & 700 & 0.163 & 0.394 & 0.001 \\
& 700 & 0.144 & 0.394 & 0.001 \\
& 900 & 0.293 & 1.000 & 0.000 \\
& 1000 & 0.204 & 0.484 & 0.001 \\
& 1300 & 0.247 & 1.000 & 0.000 \\
& 1500 & 0.317 & 1.000 & 0.000 \\
\hline
\end{tabular}

${ }^{1} \mathrm{PiaPAL}=$ piapara Palotina; ${ }^{2} \mathrm{PiaSG}=$ piapara Salto Grande; ${ }^{3} \mathrm{P}:$ probability.

Table 4. Number of specimens (N), Shannon Index (SI) and percentage of polymorphic fragments (PF) for $P$. mesopotamicus and L. elongatus broodstocks.

\begin{tabular}{cccc}
\hline Broodstocks & $\mathrm{N}$ & $\mathrm{SI}$ & $\% \mathrm{PF}$ \\
\hline PacPAL $^{2}$ & 30 & 0.408 & 65.6 \\
PacSG $^{1}$ & 30 & 0.347 & 57.3 \\
PiaPAL $^{4}$ & 30 & 0.572 & 94.8 \\
PiaSG $^{3}$ & 30 & 0.500 & 86.5 \\
\hline
\end{tabular}

${ }^{1} \mathrm{PacSG}=$ pacu Salto Grande; ${ }^{2} \mathrm{PacPAL}=$ pacu Palotina $;{ }^{3} \mathrm{PiaSG}=$ piapara Salto Grande; ${ }^{4} \mathrm{PiaPAL}=$ piapara Palotina.

High variability in broodstocks presupposes that offspring for restocking also have high variability, making feasible their release in the rivers Paraná and Paranapanema without jeopardizing the natural populations. In broodstock samplings from the same fish pond in Salto Grande for the species $P$. mesopotamicus and L. elongatus, Povh et al. (2008a) and Gomes et al. (2008) reported rates (SI $=0.289$ and $\% \mathrm{FP}=56.36 \%$; $\mathrm{SI}=0.447$ and $\% \mathrm{FP}=88.8 \%$, respectively) similar to those in current research for PacSG and PiaSG. The above reveals good reproduction management of broodstocks and their viability in restocking programs. In another research on the genetic variability of $P$. mesopotamicus broodstocks in restocking programs in the river Paranapanema, Povh et al. (2009) reported high genetic variability $(\% \mathrm{PF}=71.4 \%-75 \%$; $\mathrm{SI}=0.376$ 0.434 ) and thus adequate reproduction management. Almeida et al. (2013) assessed the genetic variability of broodstocks (natural population) and fingerlings in a Salminus brasiliensis restocking program and observed higher percentages of polymorphic fragments in natural populations than in fry broodstocks and lower genetic diversity rates. The above corroborates the importance of adequate reproduction management for the variability of offspring.

Molecular variance (AMOVA) demonstrated that most variations lay within each broodstock and not between the broodstocks (89.77 for P. mesopotamicus and 89.73 for L. elongatus). Likewise, distance (0.088 and 0.142 for P. mesopotamicus and $L$. elongatus, respectively) and genetic identity (0.916 and 0.868 for P. mesopotamicus and L. elongatus, respectively) demonstrated similarity among the broodstocks of each species (Table 5). Results seem to show that broodstocks had a common ancestry. The hypothesis has been confirmed by the lack of exclusive fragments in the broodstocks of each species, Fst rate $(0.1023$ and 0.1027 for $P$. mesopotamicus and L. elongatus, respectively) and $\mathrm{Nm}$ rate (4.18 and 4,33 for P. mesopotamicus and L. elongatus, respectively) with a slight genetic difference (according to Wright's classification) with genetic flux (Table 6). 
Table 5. Analysis of molecular variance (ANOVA), variation source (VS), sum of squares (SSQ), coefficient of variation $(\mathrm{CV})$, percentage of variation $(\% \mathrm{~V})$, distance (D) and genetic identity (I) for P. mesopotamicus and $L$. elongatus broodstocks.

\begin{tabular}{ccccccc}
\hline Groupings & VS & SSQ & CV & $\% \mathrm{~V}$ & $\mathrm{D}$ & $\mathrm{I}$ \\
\hline \multirow{3}{*}{ PacPAL $^{1} \times$ PacSG $^{2}$} & E.L & 45.900 & 1.18379 & $10.23^{*}$ & 0.088 & 0.916 \\
& D.L & 602.400 & 10.38621 & 89.77 & & \\
\cline { 2 - 7 } & Total & 648.300 & 11.57000 & 100 & & \\
\hline \multirow{3}{*}{ PiaPAL $^{3} \times$ PiaSG $^{4}$} & E.1 & 92.100 & 2.37770 & $10.27^{*}$ & 0.142 & 0.868 \\
& D.L & 1204.600 & 20.76897 & 89.73 & & \\
\cline { 2 - 7 } & Total & 1296.700 & 23.14667 & 100 & & \\
\hline
\end{tabular}

$* \mathrm{P}<0.05$. E.L. $=$ between broodstocks. D.L. $=$ within broodstocks. ${ }^{1} \mathrm{PacPAL}=$ pacu Palotina; ${ }^{2} \mathrm{PacSG}=$ pacu Salto Grande; ${ }^{3} \mathrm{PiaPAL}$ $=$ piapara Palotina; ${ }^{4} \mathrm{PiaSG}=$ piapara Salto Grande.

Table 6. Fst, $\mathrm{X}^{2}$ test for Fst, genetic difference according to Wright (1978) and number of emigrants (Nm) for different groupings analyzed in P. mesopotamicus and L. elongatus broodstocks.

\begin{tabular}{|c|c|c|c|c|}
\hline Groupings & Fst & Wright & $X^{2}$ & $\mathrm{Nm}$ \\
\hline $\mathrm{PacPAL}^{1} \times \mathrm{PacSG}^{2}$ & $0.1023 *$ & Fair & 6.138 & 4.18 \\
\hline $\mathrm{PiaPAL}^{3} \times \mathrm{PiaSG}^{4}$ & $0.1027 *$ & Fair & 6.162 & 4.33 \\
\hline
\end{tabular}

$* \mathrm{P}<0.05 .{ }^{1} \mathrm{PacPAL}=$ pacu Palotina; ${ }^{2} \mathrm{PacSG}=$ pacu Salto Grande; ${ }^{3} \mathrm{PiaPAL}=$ piapara Palotina; ${ }^{4} \mathrm{PiaSG}=$ piapara Salto Grande.

Sporadic introductions of new broodstocks from natural populations or from broodstocks in captivity are normally used to increase the genetic variability of broodstocks in restocking programs (LOPERABARRERO et al., 2010). However, results in current analysis do not recommend an exchange of P. mesopotamicus and L. elongatus broodstocks between the fish ponds analyzed since their genetic similarity shuns the insertion of a new pool that improves conditions in restocking programs. On the contrary, no restrictions are recommended if exchange aims at replacing old broodstocks or those lost due to mortality.

High rates of intra-population genetic variability were reported within each broodstock, showing that the formation of broodstocks and the reproduction and genetic management were efficiently undertaken in the fish ponds studied. On the other hand, inter-population rates demonstrated similarity between broodstocks from each species and common ancestry. Results show the relevance of genetic analyses in conservation programs with fish restocking.

\section{Acknowledgements}

The authors would like to thank the members of the Research Nucleus PeixeGen and the owners of the fish ponds for their collaboration in current assay.

\section{References}

ABD EL NABY, W. S. H.; NASR, S. M.; SHOURBELA, R. M. Genetic variation among four species of Tilapia and their hybrid in Egypt using Random Amplified Polymorphic DNA (RAPD) analysis. Alexandria Journal of Veterinary Sciences, Alexandria, v. 47, n. 1, p. 201208, 2015.

ALMEIDA, F. S. de; LOPES, C. M.; ORSI, M. L.; SIROL, R. N.; SODRÉ, L. M. K. Genetic monitoring by RAPD markers for repopulation programs of Salminus brasiliensis (Pisces, Characiformes). Acta Scientiarum. Animal Sciences, Maringá, v. 35, n. 2, p. 119-126, 2013. 
BEHRMANN, K.; REHBEIN, H.; VON APPEN, A.; FISCHER, M. Applying population genetics for authentication of marine fish: the case of saithe (Pollachius virens). Journal of Agricultural and Food Chemistry, München, v. 63, n. 3, p. 802-809, 2015.

BOSCOLO, W. R.; SIGNOR, A.; FREITAS, J. M. A.; BITTENCOURT, F.; FEIDEN, A. Nutrição de peixes nativos. Revista Brasileira de Zootecnia, Viçosa, MG, v. 40, p. 145-154, 2011. Suplemento.

EXCOFFIER, L.; LAVAL, G.; SCHNEIDER, S. Arlequin ver. 3.0: an integrated software package for population genetics data analysis. Evolutionary Bioinformatics Online, Auckland, v. 2005, n. 1, p. 47-50, 2007.

EXCOFFIER, L.; SMOUSE, P. E.; QUATTRO, J. M. Analysis of molecular variance inferred from metric distances among DNA haplotypes: application to human mitochondrial DNA restriction data. Genetics, Austin, v. 131, n. 2, p. 479-491, 1992.

GANAIE, H. A.; ALI, M. N. Studies on the genetic variability of three fish species (Cyprinus carpio specularis, Cyprinus carpio communis and Oncorhynchus mykiss) collected from Kashmir (India) using Random Amplified Polymorphic DNA (RAPD) technique. Asian Journal of Animal Sciences, Dubai, v. 10, n. 1, p. 59-67, 2016.

GOMES, P. C.; LOPERA-BARRERO, N. M.; VARGAS, L.; STREIT JUNIOR, D. P.; POVH, J. A.; SIROL, R. N.; RIBEIRO, R. P. Genetic diversity of Salminus brasiliensis (Characiformes: Characidae) collected in the passage ladder of the Canoas I hydropower plant in the Paranapanema River, Brazil. Semina: Ciências Agrárias, Londrina, v. 34, n. 3, p. 1421-1432, 2013.

GOMES, P. C.; RIBEIRO, R. P.; LOPERA-BARRERO, N. M.; POVH, J. A.; VARGAS, L.; SIROL, R. N. Diversidade genética de três estoques de piapara (Leporinus elongatus), utilizando RAPD. Acta Scientiarum Animal Science, Maringá, v. 30, n. 2, p. 241247, 2008.

HASAN, I.; GOSWAMI, M. M. Genetic variation among cat fish (Mystus vittatus) population assessed by Randomly Amplified Polymorphic (RAPD) markers from Assam, India. Journal of Aquaculture Research \& Development, Roma, v. 6, n. 4, p. 1-4, 2015.

HATANAKA, T.; HENRIQUE-SILVA, F.; GALETTI JUNIOR, P. M. Population substructuring in a migratory freshwater fish Prochilodus argenteus (Characiformes, Prochilodontidae) from the São Francisco River. Genética, Dordrecht, v. 126, n. 1, p. 513-517, 2006.
LOPERA-BARRERO, N. M. Conservation of Brycon orbignyanus natural populations and stocks for their reproductive, genetic, environmental sustainability: a model for species threatened with extinction. Ciencia e Investigación Agraria, Santiago, v. 36, n. 2, p. 191-208, 2009.

LOPERA-BARRERO, N. M.; POVH, J. A.; RIBEIRO, R. P.; GOMES, P. C.; JACOMETO, C. B.; LOPES, T. S. Comparación de protocolos de extracción de ADN con muestras de aleta y larva de peces: extracción modificada con cloruro de sodio. Ciencia e Investigación Agraria, Santiago, v. 35, n. 1, p. 76-86, 2008.

LOPERA-BARRERO, N. M.; RIBEIRO, R. P.; VARGAS, L.; POVH, J. A.; LOPES, T. S.; OLIVEIRA, S. N.; GOMES, P. C. Diversidad genética de Piaractus mesopotamicus utilizado em programas de repoblación. Archivos de Zootecnia, Córdoba, v. 59, n. 225, p. 51-62, 2010.

LOPERA-BARRERO, N. M.; RODRIGUEZRODRIGUEZ, M. P.; FORNARI, D. C.; RESENDE, E. K.; POVEDA-PARRA, A. R.; BRACCINI, G.; SOUZA, F. P.; FURLAN, P. J.; POVH, J. A.; RIBEIRO, R. P. Genetic variability of broodstocks of Tambaqui (Teleostei - Characidae) from the northeast region of Brazil. Semina: Ciências Agrárias, Londrina, v. 36, n. 6, p. 4013-4022, 2015.

MARENGONI, N. G.; MACHADO, M. R. F.; GASPARIN, E. Extração de DNA genômico em tecidos sólidos de peixes teleósteos. Semina: Ciências Agrárias, Londrina, v. 27, n. 1, p. 99-106, 2006.

MILLER, M. P. Tools for population genetic analyses (TFPGA): a Windows program for the analysis of allozyme and molecular population genetic data. Version 1. 3. Flagstaff: Northern Arizona University, 1997. 33 p.

NEI, M. Estimation of average heterozygosity and genetic distance from a small number on individual. Genetics, Austin, v. 89, n. 3, p. 583-590, 1978.

POVH, J. A.; LOPERA-BARRERO, N. M.; RIBEIRO, R. P.; LUPCHINSKI JUNIOR, E.; GOMES, P. C.; LOPES, T. S. Monitoreo genético en programas de repoblamiento de peces mediante marcadores moleculares. Ciencia e Investigación Agrária, Santiago, v. 35, n. 1, p. 5-15, $2008 \mathrm{~b}$.

POVH, J. A.; RIBEIRO, R. P.; LOPERA-BARRERO, N. M.; GOMES, P. C.; BLANCK, D. V.; VARGAS, L.; JACOMETO, C. B.; LOPES, T. S. Monitoramento da variabilidade genética de pacu, Piaractus mesopotamicus do programa de aumento de estoque do rio Paranapanema. Arquivo Brasileiro de Medicina Veterinária e Zootecnia, Belo Horizonte, v. 61, n. 5, p. 1191-1195, 2009. 
POVH, J. A.; RIBEIRO, R. P.; SIROL, R. N.; STREIT JUNIOR, D. P.; LOPERA-BARRERO, N. M.; VARGAS, L.; GOMES, P. C.; LOPES, T. S. Diversidade genética de pacu do rio Paranapanema e do estoque de um programa de repovoamento. Pesquisa Agropecuária Brasileira, Brasília, v. 43, n. 2, p. 201-206, 2008a.

RAMOS, J. V. B.; SODRÉ, L. M. K.; ORSI, L. M.; ALMEIDA, F. S. Genetic diversity of the species Leporinus elongatus (Teleostei: Characiformes) in the Canoas Complex - Paranapanema River. Neotropical Ichtiology, Maringá, v. 10, n. 4, p. 821-828, 2012.

RAYMOND, M.; ROUSSET, F. An exact test for population differentiation. Evolution, Lancaster, v. 49, n. 6, p. 1280-1283, 1995.

RIBEIRO, R. P.; LOPERA-BERRERO, N. M.; POVH, J. A.; RODRIGUEZ-RODRIGUEZ, M. P.; FORNARI, D. C.; BAUMGARTNER, G.; BAUMGARTNER, D.; SOUZA, F. P.; CASTRO, P. L.; POVEDA-PARRA, A. R. Genetic diversity of Salminus brasiliensis wild populations in downstream and upstream Cachoeira -Branca, Verde River MS Brazil: a preliminary view. Semina: Ciências Agrárias, Londrina, v. 37, n. 1, p. 507-516, 2016.

SIROL, R. N.; BRITTO, S. G. Conservação e manejo da ictiofauna: repovoamento. In: NOGUEIRA, M. G.; HENRY, R.; JORCIN, A. (Ed.). Ecologia de reservatórios: impactos potenciais, ações de manejo e sistemas em cascata. São Carlos: Rima, 2006. p. 275-284.
TELLES, M. P. C.; MONTEIRO, M. S. R.; RODRIGUES, F. M.; SOARES, T. N.; RESENDE, L. V.; AMARAL, A. G.; MARRA, P. R. Marcadores RAPD na análise de divergência genética entre raças de bovinos e número de locos necessários para a estabilidade da divergência estimada. Ciência Animal Brasileira, Goiânia, v. 2, n. 2, p. 87-95, 2001.

WEIR, B. S.; COCKERHAM, C. C. Estimating F statistics for the analysis of population structure. Evolution, Lancaster, v. 38, n. 6, p. 1358-1370, 1984.

WILLIAMS, J. G. K.; RAFALSKI, J. A.; KUBELIK, A. R.; LIVAK, K. J.; TINGEY, S. V. DNA polymorphism amplified by arbitrary primers are useful as genetic markers. Nucleic Acids Research, Oxford v. 18, n. 22, p. 6531-6535, 1990.

WORKMAN, P. L.; NISWANDER, J. L. Population studies on southwestern indian tribes. II. Local genetic differentiation in the Papago. American Journal Human Genetic, Houston, v. 22, n. 1, p. 24-49, 1970.

WRIGHT, S. Evolution and genetics of populations. Chicago: University of Chicago Press, 1978. 511 p.

YEH, F. C.; BOYLE, T. Y. Z.; XIYAN, J. M. PopGene version 131: Microsoft Window-based freeware for population genetic analysis. Alberta: University of Alberta and Center for International Forestry Research, 1999. 29 p. 
